\title{
Efficacy and safety of cyclosporine a for patients with steroid-resistant nephrotic syndrome: a meta-analysis
}

\author{
Hong-Yan Li ${ }^{1+}$, Xialan Zhang ${ }^{2 \dagger}$, Tianbiao Zhou ${ }^{3 *}$, Zhiqing Zhong ${ }^{3}$ and Hongzhen Zhong ${ }^{3}$
}

\begin{abstract}
Background: The purpose of this study was to determine efficacy and safety of cyclosporine A (CsA) for patients with steroid-resistant nephrotic syndrome (SRNS).

Methods: The Cochrane Library and PubMed were searched to extract the associated studies on Oct 10, 2018, and the meta-analysis method was used to pool and analyze the applicable investigations included in this study. The P(opulation) I(ntervention) C(omparison) O(utcome) of the study were defined as follows: P: Patients with SRNS; I: treated with CsA, cyclophosphamide (CYC), tacrolimus (TAC) or placebo/not treatment (P/NT); C: CsA vs. placebo/nontreatment (P/NT), CsA vs. CYC, CsA vs. TAC; O: complete remission (CR), total remission (TR; complete or partial remission (PR)), urine erythrocyte number, proteinuria levels, albumin, proteinuria, serum creatinine, and plasma cholesterol, etc. Data were extracted and pooled using RevMan 5.3.

Results: In the therapeutic regimen of CSA vs. placebo/nontreatment (P/NT), the results indicated that the CsA group had high values of $C R$, TR, and low values of proteinuria, serum creatinine, and plasma cholesterol when compared with those in the placebo group. In comparing CsA vs. cyclophosphamide (CYC), the results indicated that the CsA group had higher TR than the CYC group. In comparing CSA vs. tacrolimus (TAC), the results revealed insignificant differences in CR, and TR between the CsA and TAC groups. The safety of CsA was also assessed. The incidence of gum hyperplasia in CsA group was higher than that in the P/NT group, with no differences in incidence of infections or hypertension between CSA and P/NT groups. There was no difference in the incidence of hypertension between the CSA and TAC groups.
\end{abstract}

Conclusions: CSA is an effective and safe agent in the therapy of patients with SRNS.

Keywords: Cyclosporine a (CSA), Steroid-resistant nephrotic syndrome (SRNS), Complete remission (CR), Total remission (TR), Meta-analysis

\section{Background}

Nephrotic syndrome (NS), characterized by hypoalbuminemia, massive proteinuria, peripheral edema, and hyperlipidemia, is a major cause of end-stage renal disease (ESRD), and related damage of the glomerular filtration barrier [1-3]. Based on the response to steroid therapy, NS is classified as steroid-sensitive nephrotic syndrome (SSNS, approximately 50\% of SSNS patients develop frequently-relapsing nephrotic syndrome or steroiddependent nephrotic syndrome), or steroid-resistant

\footnotetext{
* Correspondence: zhoutb@aliyun.com

Hong-Yan Li and Xialan Zhang should be regarded as joint First Authors.

${ }^{3}$ Department of Nephrology, the Second Affiliated Hospital of Shantou

University Medical College, Shantou 515041, China

Full list of author information is available at the end of the article
}

nephrotic syndrome (SRNS) [1, 4-6]. Patients who do not enter remission after administration of daily prednisolone for 4 weeks are regarded as SRNS [7]. SRNS is regarded as one of the most common causes of the development of ESRD in children [8]. The current therapeutic options for SRNS are often ineffective, it frequently progresses to a loss of kidney function, and treatment is often complicated by significant toxicity associated morbidities, mortality, and cost $[1,8]$.

Cyclosporine A (CsA) is one of the most widely used immunosuppressants in organ transplantation and in the treatment of various immunological diseases $[9,10]$. CsA is frequently used to treat SRNS and can induce remission [11, 12]. However, CsA also exerts nephrotoxic

(C) The Author(s). 2019 Open Access This article is distributed under the terms of the Creative Commons Attribution 4.0 International License (http://creativecommons.org/licenses/by/4.0/), which permits unrestricted use, distribution, and 
effects, as demonstrated by increased tubulointerstitial fibrosis, inflammation and podocyte damage [13, 14]. In the current study, we performed a meta-analysis to assess the safety and efficacy of CsA in the treatment of patients with SRNS.

\section{Methods}

\section{Data sources and search strategy}

The systematic search strategy was conducted in the Cochrane Library and PubMed without language restrictions, from inception to Oct 10, 2018. We conducted searches by using the search strategy: cyclosporine AND (nephrotic syndrome OR glomerulonephritis membranoproliferative OR focal segment glomerulosclerosis OR minimal change nephrotic syndrome OR membranoproliferative glomerulonephritis). We also checked the references cited in the published studies for additional studies.

\section{Inclusion and exclusion criteria Inclusion criteria}

In this study, the inclusion criteria were as follows: (1) investigation type: randomized controlled trials; (2) object of the study: patients were diagnosed with NS and the NS was resistant to the steroid treatment; (3) type of interventions: treatment regimens based on CsA, the controls should have been treated with another immunotherapy or placebo.

\section{Exclusion criteria}

Exclusion criteria for the study were as follows: (1) Reviews, case reports, letters, systematic reviews, and metaanalysis; (2) Patients with nephrotic syndrome were sensitive to steroid or dependent to steroid; (3) studies that do not contain different therapeutic regimens; (4) the diagnostic criteria were not clear.

\section{Analyzed outcomes}

Efficacy of CsA: primary outcomes were complete remission (CR) and total remission (TR; CR or partial remission (PR)). The secondary outcomes were biological indicators including proteinuria levels, serum creatinine, serum albumin and plasma cholesterol.

Safety of CsA: adverse events including infection, hypertension and gum hyperplasia.

The CR was defined as proteinuria $<4 \mathrm{mg} / \mathrm{m}^{2} / \mathrm{hr}$. (children) or $0.2 \mathrm{~g} /$ day (adults), for three non-consecutive days. PR was defined as the proteinuria $<40 \mathrm{mg} / \mathrm{m}^{2} / \mathrm{hr}$. (children) or $3.5 \mathrm{~g} /$ day (adults) for three different non-consecutive days.

\section{Data collection}

According to the predetermined inclusion criteria, two independent reviewers scanned the titles and abstracts of the included records. Full texts of potentially literature were read for further screening. Discordant opinions were discussed and resolved by other reviewers.

The extraction data included the (1) the first author and publication year, (2) study design features, (3) baseline characteristics of study participants, and (4) study outcomes (e.g., efficacy and safety outcomes). The $\mathrm{P}$ (opulation) I(ntervention) $\mathrm{C}$ (omparison) $\mathrm{O}$ (utcome) of the study were defined as follows: P: Patients with SRNS; I: treated with CsA, CYC, tacrolimus (TAC) or placebo/ not treatment (P/NT); C: CsA vs. placebo/nontreatment (P/NT), CsA vs. cyclophosphamide (CYC), CsA vs. TAC; $\mathrm{O}: \mathrm{CR}, \mathrm{TR}$, urine erythrocyte number, proteinuria levels, albumin, proteinuria, serum creatinine, and plasma cholesterol, etc.

\section{Quality assessment}

Two abstractors independently evaluated the methodological quality of all the eligible clinical trials according to the Modified Jadad Scale[15]. The studies were scored by answering the following questions:

Randomization:

1. Was the trial random?

2. Was the randomization procedure adequately explained?

Allocation concealment:

1. Did the trial use a random assignment method?

2. Was the allocation concealment appropriate so that the clinicians and the subjects could not predict how the sequence would be assigned?

Blinding method:

1. Was the trial double-blind?

2. Did the trial use a placebo or similar methods?

Withdrawals and dropouts:

1. Were the numbers and reasons for withdrawals and dropouts adequately explained?

If the answer to each question was YES, the study would get 1 point; if $\mathrm{NO}$, the study would get 0 point. A score of more than 3 was considered as high quality.

\section{Statistical analysis}

The data were extracted from the included literature, and the results were evaluated using Review Manager Version 5.3 software (Revman the Cochrane Collaboration; England). Continuous data were expressed using weighted mean differences (WMDs), and dichotomous data were expressed using the odds ratio (OR). 95\% confidence intervals (95\% CI) with the Mantel-Haenszel (M-H) method were used for the included studies. 
Table 1 Characteristics of the studies included in this meta-analysis

\begin{tabular}{|c|c|c|c|c|c|c|}
\hline $\begin{array}{l}\text { Author, } \\
\text { year }\end{array}$ & Study design & $\begin{array}{l}\text { Treatment } \\
\text { strategies }\end{array}$ & Detailed scheme & Patient characteristics & Main Outcome Measures & adverse events \\
\hline Garin 1988 & $\begin{array}{l}\text { Single } \\
\text { center, cross- } \\
\text { over, ran- } \\
\text { domized } \\
\text { clinical trial }\end{array}$ & $\begin{array}{l}\text { CsA vs. P/ } \\
\text { NT }\end{array}$ & $\begin{array}{l}\text { In CsA group, the initial } \\
\text { dosage was } 5 \mathrm{mg} / \mathrm{kg} / \mathrm{d} \text {, } \\
\text { and then sustained } 200 \\
\mathrm{ng} / \mathrm{ml} \text { or less. The total } \\
\text { treatment course was } 8 \\
\text { weeks. In control group, } \\
\text { any immunosuppressive } \\
\text { agent was not allowed. }\end{array}$ & $\begin{array}{l}\text { Six male and two females } \\
\text { with idiopathic, SRNS } \\
\text { were enrolled. The } \\
\text { median age was } 12(3,18) \\
\text { years. Four patients had } \\
\text { MCD and the other four } \\
\text { were diagnosed with } \\
\text { FSGS. All the patients } \\
\text { were Children. Initially, } \\
\text { four patients in group of } \\
\text { CSA and four patients in } \\
\text { P/NT group. }\end{array}$ & $\begin{array}{l}\text { Urinary protein excretion } \\
\text { values, creatinine } \\
\text { clearance values, serum } \\
\text { albumin values, etc. }\end{array}$ & $\begin{array}{l}\text { Hypertension, renal } \\
\text { function deterioration, } \\
\text { liver function disorder, } \\
\text { etc. }\end{array}$ \\
\hline $\begin{array}{l}\text { Ponticelli } \\
1993\end{array}$ & $\begin{array}{l}\text { Multicenter } \\
\text { randomized } \\
\text { clinical trial }\end{array}$ & $\begin{array}{l}\text { CsA vs. P/ } \\
\text { NT }\end{array}$ & $\begin{array}{l}\text { CsA was administered } \\
\text { orally and the initial dose } \\
\text { was divided into two } \\
\text { doses ( } 6 \mathrm{mg} / \mathrm{kg} / \mathrm{day} \text { for } \\
\text { children and } 5 \mathrm{mg} / \mathrm{kg} / \mathrm{day} \\
\text { for adults). The CsA level } \\
\text { was maintained between } \\
250 \text { and } 600 \mathrm{ng} / \mathrm{ml} \text {, and } \\
\text { CsA discontinued after six } \\
\text { months. For patients who } \\
\text { responded, the CsA dose } \\
\text { was reduced by } 25 \% \\
\text { every two months, so that } \\
\text { CsA treatment was } \\
\text { stopped by the end of } \\
\text { the year. Patients in } \\
\text { control group were given } \\
\text { only supportive treatment } \\
\text { for one year. }\end{array}$ & 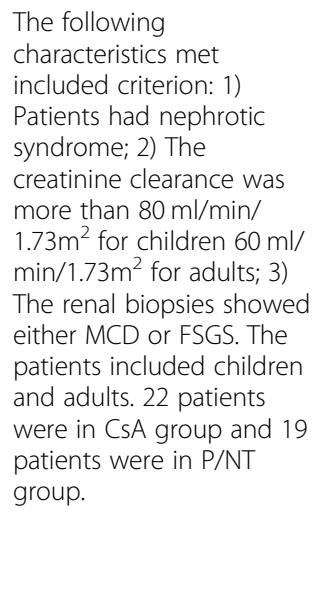 & $\begin{array}{l}\text { CR, TR, proteinuria, } \\
\text { serum creatinine, } \\
\text { creatinine clearance } \\
\text { values, serum urea, } \\
\text { serum proteins, serum } \\
\text { albumin values, plasma } \\
\text { cholesterol, etc. }\end{array}$ & $\begin{array}{l}\text { Infections, gum } \\
\text { hyperplasia, } \\
\text { hypertrichosis, transient } \\
\text { gastric discomfort, } \\
\text { conjugated } \\
\text { bilirubinemia, headache, } \\
\text { bronchospasm, } \\
\text { paresthesia, etc. }\end{array}$ \\
\hline $\begin{array}{l}\text { Lieberman } \\
1996\end{array}$ & $\begin{array}{l}\text { Multicenter } \\
\text { randomized } \\
\text { clinical trial }\end{array}$ & $\begin{array}{l}\text { CsA vs. P/ } \\
\text { NT }\end{array}$ & $\begin{array}{l}\text { CsA was administered as } \\
\text { the } 100 \mathrm{mg} / \mathrm{ml} \\
\text { suspension. The initial } \\
\text { dose was } 3 \mathrm{mg} / \mathrm{kg} \text { of CsA } \\
\text { twice daily as to attaining } \\
\text { a target CsA level within } \\
\text { the range of } 300 \text { to } 500 \\
\text { ng/mL. Placebo patients } \\
\text { were received a vehicle } \\
\text { control. }\end{array}$ & $\begin{array}{l}\text { Age of patients was } \\
\text { between } 6 \text { months and } \\
21 \text { years. } 15 \text { patients were } \\
\text { in CsA group and } 15 \\
\text { patients were in P/NT } \\
\text { group. }\end{array}$ & $\begin{array}{l}\text { CR, TR, proteinuria, } \\
\text { serum creatinine, serum } \\
\text { albumin values, plasma } \\
\text { cholesterol, potassium, } \\
\text { uric acid, magnesium, } \\
\text { etc. }\end{array}$ & $\begin{array}{l}\text { Infections, hypertension, } \\
\text { gum hyperplasia, etc. }\end{array}$ \\
\hline Plank 2008 & $\begin{array}{l}\text { Multicenter } \\
\text { randomized } \\
\text { clinical trial }\end{array}$ & $\begin{array}{l}\text { CSA vs. } \\
\text { CYC }\end{array}$ & $\begin{array}{l}\text { The initial dose of CsA } \\
\text { was } 150 \mathrm{mg} / \mathrm{m}^{2} \mathrm{BSA} \text { twice } \\
\text { per day in CsA group. If } \\
\text { the proteinura decrease < } \\
40 \mathrm{mg} / \mathrm{m}^{2} / \text { hour within the } \\
\text { first } 12 \text { weeks during the } \\
\mathrm{CsA} \text { therapy, patients } \\
\text { were recruited into the } \\
\text { non-responder protocol } \\
\text { with CsA dose increasing } \\
\text { to } 350 \mathrm{ng} / \mathrm{ml} \text { (range } 300- \\
400 \mathrm{ng} / \mathrm{ml}) \text {. In control } \\
\text { group, patients were ad- } \\
\text { ministered } 500 \mathrm{mg} / \mathrm{m}^{2} \\
\text { BSA CYC pulse therapy in } \\
\text { a } 4-h \text { infusion. The infu- } \\
\text { sion treatment was re- } \\
\text { peated in 4,8,12,16,24 and } \\
36 \text { weeks. }\end{array}$ & $\begin{array}{l}\text { Patients from children } \\
\text { with gross proteinuria > } \\
40 \mathrm{mg} / \mathrm{m}^{2} \mathrm{BSA} \text { per hour } \\
\text { (equivalent to } 1 \mathrm{~g} / \mathrm{m}^{2} / 24 \mathrm{~h} \text { ) } \\
\text { and hypoalbuminemia (< } \\
25 \mathrm{~g} / \mathrm{l} \text { ) were included. All } \\
\text { patients were diagnosed } \\
\text { as MCD, FSGS or diffuse } \\
\text { mesangial proliferation by } \\
\text { renal biopsy. } 15 \text { patients } \\
\text { were in CsA group and } 17 \\
\text { patients were in CYC } \\
\text { group. }\end{array}$ & $C R$, TR, etc. & $\begin{array}{l}\text { Infections, hypertension, } \\
\text { headache, gum } \\
\text { hyperplasia, } \\
\text { hypertrichosis, transient } \\
\text { gastric discomfort, etc. }\end{array}$ \\
\hline $\begin{array}{l}\text { Choudhry } \\
2009\end{array}$ & $\begin{array}{l}\text { Single center } \\
\text { Randomized } \\
\text { clinical trial }\end{array}$ & $\begin{array}{l}\text { CsA vs. } \\
\text { TAC }\end{array}$ & $\begin{array}{l}\text { The initial dose of TAC } \\
\text { was } 0.1 \text { to } 0.2 \mathrm{mg} / \mathrm{kg} / \mathrm{d} \text { or } \\
\text { CsA at } 5 \text { to } 6 \mathrm{mg} / \mathrm{kg} / \mathrm{d} \text { in } \\
\text { two divided doses for } 12- \\
\text { month. Patients in two }\end{array}$ & $\begin{array}{l}\text { Patients with the } \\
\text { following traits were } \\
\text { eligible for study 1) Age } \\
\text { ranged from } 1 \text { to } 18 \text { years } \\
\text { with idiopathic SRNS; 2) }\end{array}$ & $C R$, TR, etc. & $\begin{array}{l}\text { Infections, hypertension, } \\
\text { headache, gum } \\
\text { hyperplasia, } \\
\text { hypertrichosis, } \\
\text { paresthesia, etc. }\end{array}$ \\
\hline
\end{tabular}


Table 1 Characteristics of the studies included in this meta-analysis (Continued)

\begin{tabular}{|c|c|c|c|c|c|c|}
\hline $\begin{array}{l}\text { Author, } \\
\text { year }\end{array}$ & Study design & $\begin{array}{l}\text { Treatment } \\
\text { strategies }\end{array}$ & Detailed scheme & Patient characteristics & Main Outcome Measures & adverse events \\
\hline & & & $\begin{array}{l}\text { groups got oral prednisol- } \\
\text { one } 1 \mathrm{mg} / \mathrm{kg} \text { (on alternate } \\
\text { days) for } 6 \text { months, } \\
\text { followed by } 0.5 \mathrm{mg} / \mathrm{kg} \text { for } \\
\text { the next } 6 \text {-month, and } \\
\text { enalapril was administered } \\
\text { at the dose of } 0.2 \text { to } 0.3 \\
\mathrm{mg} / \mathrm{kg} / \mathrm{d} \text {. }\end{array}$ & $\begin{array}{l}\text { Renal histological } \\
\text { characteristics suggested } \\
\text { of MCD, } \\
\text { mesangioproliferative } \\
\text { glomerulonephritis or } \\
\text { FSGS. } 20 \text { patients were in } \\
\text { CsA group and } 21 \\
\text { patients were in TAC } \\
\text { group. }\end{array}$ & & \\
\hline Geng 2018 & $\begin{array}{l}\text { Single center } \\
\text { Randomized } \\
\text { clinical trial }\end{array}$ & $\begin{array}{l}\text { CsA vs. } \\
\text { MMF }\end{array}$ & $\begin{array}{l}\text { In CsA group, CsA was } \\
\text { administered orally } 3 \sim 5 \\
\mathrm{mg} / \mathrm{kg} \text { twice a day, and } \\
\text { maintained between } 80 \\
\text { and } 120 \mu \mathrm{g} / \mathrm{L} \text {. The } \\
\text { maintenance dose of } \\
\text { effective patients was } 1-3 \\
\mathrm{mg} /(\mathrm{kg} \cdot \mathrm{d}) \text { and their } \\
\text { induction period was } \\
\text { reduced after } 6 \text { months. In } \\
\text { MMF group, the dose was } \\
\text { administered orally in } 2 \\
\text { patterns, either } 15-30 \mathrm{mg} / \\
\text { ( } \mathrm{kg} \cdot \mathrm{d}) \text { or } 800 \sim 1200 \mathrm{mg} / \\
\left.\text { ( } \mathrm{m}^{2} \cdot \mathrm{d}\right) \text {. The MMF was } \\
\text { discontinued if the } \\
\text { decreasing in proteinuria } \\
\text { was less than } 50 \% \text {, or } \\
\text { continued to treat after } 6 \\
\text { months of induction with } \\
\text { maintenance dose of } 10- \\
20 \text { mg/(kg.d). The total } \\
\text { course was } 12 \text { months. }\end{array}$ & $\begin{array}{l}30 \text { pediatric patients aged } \\
\text { from } 2.1 \text { to } 17.0 \text { years } \\
\text { presented with SRNS. The } \\
\text { renal histological } \\
\text { characteristics indicated } \\
\text { MCD, } \\
\text { mesangioproliferative } \\
\text { glomerulonephritis, MN or } \\
\text { FSGS. } 18 \text { patients were in } \\
\text { CsA group and } 14 \\
\text { patients were in MMF } \\
\text { group. }\end{array}$ & $C R$, $T R$, etc. & $\begin{array}{l}\text { Respiratory infections, } \\
\text { nausea, vomiting, } \\
\text { abdominal pain, diarrhea } \\
\text { and other } \\
\text { gastrointestinal } \\
\text { symptoms, etc. }\end{array}$ \\
\hline
\end{tabular}

Note: SRNS steroid-resistant nephrotic syndrome; CSA cyclosporine A; TAC tacrolimus; CYC cyclophosphamide; MMF mycophenolate mofetil; CR complete remission; TR total remission (complete or partial remission (PR)); P/NT placebo/nontreatment; FSGS focal segmental glomerulosclerosis; $M C D$ minimal change nephropathy; $M N$ membranous nephropathy; $h$ hour; $N A$ not available. BSA body surface area

Heterogeneity was analyzed using $\mathrm{I}^{2}$ statistics and calculated for all the meta-analyses. On the basis test of the heterogeneity, when the $p$-value less than 0.1 or the $\mathrm{I}^{2}<$ $50 \%$, a fixed effect model was used. Otherwise, the results were counted using a random effects model, and a $p$-value $<0.05$ denoted significance.

\section{Results}

\section{Search results}

Seven randomized controlled trials [16-22] related to CsA for SRNS were included (Table 1), three studies $[17,19,21]$ for CsA vs. Placebo and two studies [16, 22] for CsA vs. TAC (Table 1). The quality assessment details, obtained using the Modified Jadad Scale, are presented in Table 2.

The comparison of CsA vs. placebo/nontreatment (P/NT) Three studies $[17,19,21]$ were included in the metaanalysis to assess the efficacy of CsA in patients with SRNS. The results indicated that the CsA group had a higher $\mathrm{CR}(\mathrm{OR}=11.24,95 \% \mathrm{CI}$ : $1.90-66.68, P=0.008$; Fig. 1$)$, and TR (OR $=16.70,95 \%$ CI: 4.69-59.49, $P<$ 0.0001; Fig. 1). The CsA treatment group displayed elevated levels of albumin when compared with the $\mathrm{P} /$ NT group, although this was not statistically different (WMD = 3.38, 95\% CI: $-2.30-9.06, P=0.24$; Fig. 1 ). The CsA group had lower levels of proteinuria, serum creatinine, and plasma cholesterol when compared with the P/NT group (proteinuria: WMD $=-93.47,95 \% \mathrm{CI}:-108.52$ to $-78.42, P<0.00001$; serum creatinine: $\mathrm{WMD}=-16.08$, 95\%CI: -23.43 to $-8.73, P<0.0001$; plasma cholesterol: $\mathrm{WMD}=-0.03,95 \%$ CI: -0.04 to $-0.03, P<0.00001$; Fig. 1 ).

The safety of CsA was also assessed in patients with SRNS. The incidence rate of gum hyperplasia in the CsA group was higher than that in $\mathrm{P} / \mathrm{NT}$ group $(\mathrm{OR}=13.50$, 95\% CI: $1.66-109.84, P=0.01$ ). The incidence rates of infection or hypertension were similar between the CsA and P/NT groups (infections: $95 \% \mathrm{CI}: 0.24-2.33, \mathrm{OR}=$ $0.75, P=0.62$; hypertension: $95 \% \mathrm{CI}: 0.12-8.56, \mathrm{OR}=$ $1.00, P=1.00)$.

\section{Comparing CsA vs. CYC}

One study [20] including two comparisons was considered in the meta-analysis to assess the efficacy of CsA in patients with SRNS compared with CYC. The results indicated that the CsA group had a higher TR than the 
Table 2 Quality Assessment of Included Studies (7-point)

\begin{tabular}{|c|c|c|c|c|c|c|}
\hline Author, year & Type & Randomization & Concealment of allocation & Double blinding & $\begin{array}{l}\text { Withdrawals } \\
\text { and } \\
\text { dropouts }\end{array}$ & $\begin{array}{l}\text { Jadad } \\
\text { score }\end{array}$ \\
\hline $\begin{array}{l}\text { Ponticelli } \\
1993 \text { (CsA } \\
\text { vs. P/NT) }\end{array}$ & $\begin{array}{l}\text { An open, prospective, } \\
\text { randomized, multicentric, } \\
\text { controlled } \\
\text { study }\end{array}$ & $\begin{array}{l}\text { According to a table of } \\
\text { random numbers }\end{array}$ & $\begin{array}{l}\text { By using sealed, completely } \\
\text { opaque envelopes }\end{array}$ & Open-label & Yes & 5 \\
\hline $\begin{array}{l}\text { Lieberman } \\
\text { 1996(CsA vs. } \\
\text { P/NT) }\end{array}$ & $\begin{array}{l}\text { A double-blinded, prospect- } \\
\text { ively randomized, placebo- } \\
\text { controlled trial }\end{array}$ & $\begin{array}{l}\text { By following computer } \\
\text { based random numbers }\end{array}$ & $\begin{array}{l}\text { By using sequentially } \\
\text { labelled sealed envelopes }\end{array}$ & $\begin{array}{l}\text { Both the patients and } \\
\text { their pediatric } \\
\text { nephroboglsts were } \\
\text { blinded as to the } \\
\text { administered study } \\
\text { treatment }\end{array}$ & Yes & 7 \\
\hline $\begin{array}{l}\text { Plank } 2008 \\
\text { (CsA vs. } \\
\text { CYC) }\end{array}$ & $\begin{array}{l}\text { A controlled multicentre } \\
\text { randomized open label trial }\end{array}$ & $\begin{array}{l}\text { According to centre- } \\
\text { specific computer- } \\
\text { generated random } \\
\text { lists }\end{array}$ & $\begin{array}{l}\text { Describing as using } \\
\text { allocation concealment but } \\
\text { without any details }\end{array}$ & Open-label & Yes & 5 \\
\hline $\begin{array}{l}\text { Choudhry } \\
2009 \text { (CsA } \\
\text { vs. TAC) }\end{array}$ & $\begin{array}{l}\text { A nonblind, randomized } \\
\text { controlled trial }\end{array}$ & $\begin{array}{l}\text { By following computer } \\
\text { based random numbers }\end{array}$ & $\begin{array}{l}\text { By using serially } \\
\text { numbered opaque } \\
\text { envelopes }\end{array}$ & Open-label & No & 5 \\
\hline $\begin{array}{l}\text { Garin } 2015 \\
\text { (CsA vs. P/ } \\
\text { NT) }\end{array}$ & $\begin{array}{l}\text { A cross-over, randomized, } \\
\text { controlled trial }\end{array}$ & $\begin{array}{l}\text { Describing as a } \\
\text { randomized trial } \\
\text { without details }\end{array}$ & NA & NA & NA & 1 \\
\hline $\begin{array}{l}\text { Geng } 2018 \\
\text { (CsA vs. } \\
\text { MMF) }\end{array}$ & $\begin{array}{l}\text { A prospective, randomized } \\
\text { controlled clinical trial }\end{array}$ & $\begin{array}{l}\text { According to a table of } \\
\text { random numbers }\end{array}$ & NA & NA & Yes & 3 \\
\hline
\end{tabular}

Note: CSA cyclosporine A; CTX cyclophosphamide; TAC tacrolimus; MMF mycophenolate mofetil; NA not available

CYC group $(\mathrm{OR}=12.83,95 \% \mathrm{CI}: 3.85-42.81, \quad P<$ 0.0001). The CsA group had a higher CR than the CYC group, although there was no statistical difference $(\mathrm{OR}=$ 1.59, 95\% CI: 0.33-7.76, $P=0.57)$.

\section{Comparing CsA vs. TAC}

Two studies $[16,22]$ of CsA vs. TAC were included into the meta-analysis to assess the efficacy of CsA in patients with SRNS. There were no significant group differences in CR or TR (CR: OR $=1.71,95 \% \mathrm{CI}$ : $0.58-$ 5.04, $P=0.33$; TR: $\mathrm{OR}=0.50,95 \% \mathrm{CI}: 0.10-2.44, P=$ $0.39)$.

The safety of CsA was also assessed in patients with SRNS. There were no significant group differences in rates of hypertension (OR $=4.51,95 \%$ CI: 0.21-96.06, $P=0.33)$.

\section{Discussion}

In this systemic review and meta-analysis, we assessed the efficacy of CsA in the treatment of SRNS as well as the safety of CsA. In comparing CsA vs. placebo, the results indicated that CsA treatment increases CR, and TR and decreases proteinuria, serum creatinine, and plasma cholesterol. However, the patients from two selected studies included adults, and there was only one study on children. More studies on children or adults should be conducted to broadly assess the efficacy of CsA in the treatment of SRNS. CsA treatment did not increase rates of serious adverse events, such as infections or hypertension, but it did increase rates of gum hyperplasia. These results indicate that the CsA might be a good agent for the treatment of SRNS.

We also performed comparisons of CsA vs. CYC and CsA vs. TAC. CsA treatment results in a higher TR when compared to CYC. The CsA group also had a higher $\mathrm{CR}$ than the CYC group, although this difference was not significant. However, the number of included studies was small, and more investigations are needed to confirm these findings. In comparing CsA vs. TAC, the results indicated no group differences in $\mathrm{TR}, \mathrm{CR}$ or adverse events. This may indicate that CsA has similar efficacy and safety to TAC. CsA and TAC are two most important members of calmodulin inhibitors, and the efficacy and safety may be due to this similarity.

The number of included studies used to assess differences between CsA and mycophenolate mofetil (MMF) in the treatment of SRNS in the current analysis was small. Geng et al. [18] compared the efficacy and safety of CsA versus MMF in the treatment of children suffering from primary refractory nephrotic syndrome, and reported that CsA was superior to MMF in preventing relapses in children with frequently relapsing nephrotic syndrome and inducing complete remission in SRNS patients. Although most patients with SRNS are able to tolerate CsA and MMF, the toxicity and safety of CsA should be monitored closely. More RCTs should be conducted to assess the differences between CsA and MMF in the treatment of SRNS. 


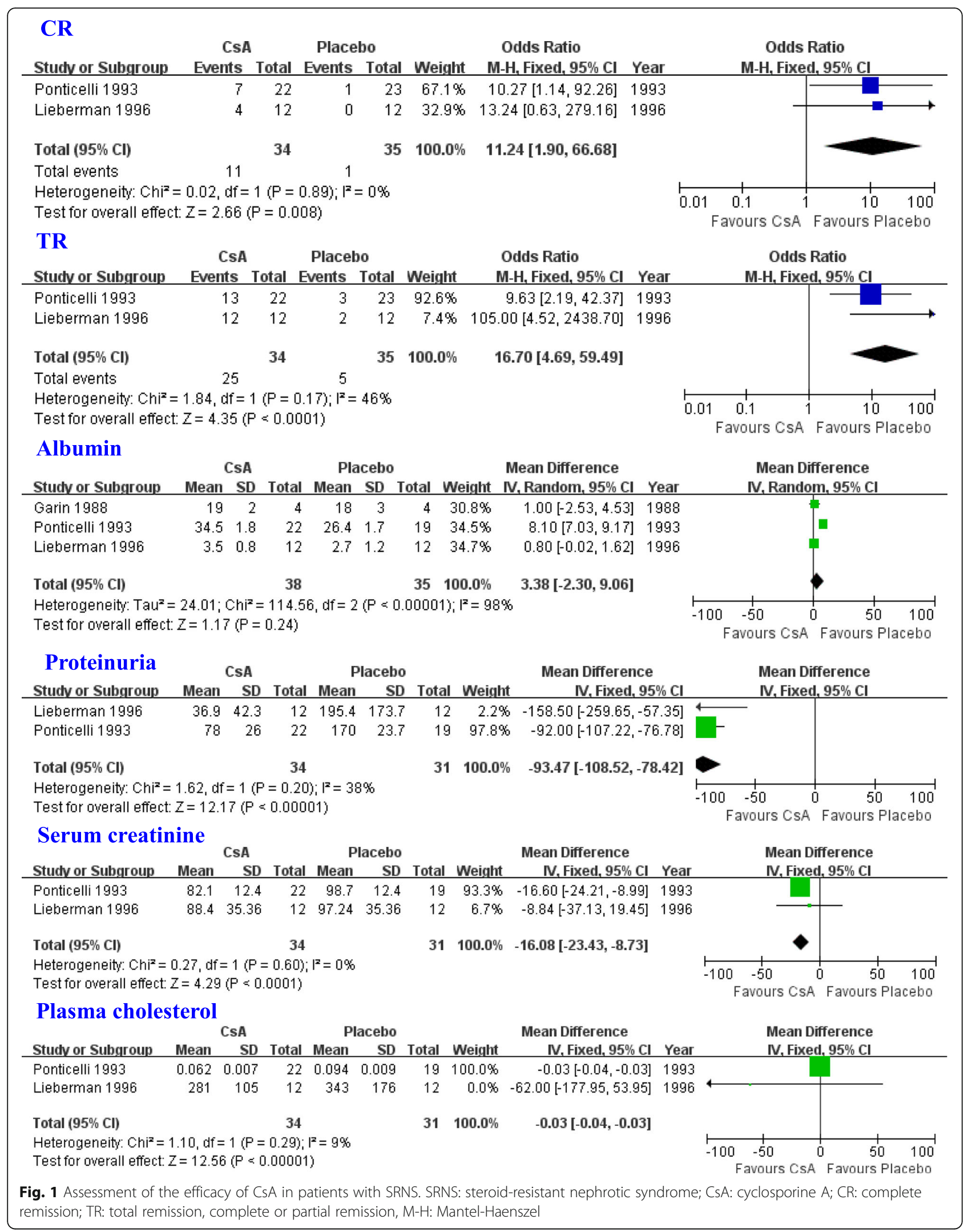


There have been two previous two meta-analyses assessing the efficacy of CsA in the treatment of SRNS. Jiang et al. [23] conducted a meta-analysis to detect the efficacy of CsA, TAC, and CYC in treating SRNS, and included four studies of CsA. They reported that CsA has superior efficacy compared to $\mathrm{CYC}$ and placebo. Hodson et al. [24] reported that CsA significantly increases the number of children who achieve CR when compared with $\mathrm{P} / \mathrm{NT}$. In our meta-analysis, we also assessed the safety of CsA in the treatment of SRNS, and found it to be a safe and effective immunosuppressive agent in the treatment of children with SRNS.

We used the modified Jadad Scale to score the included trials and observed that only one study [17] was scored less than 3 . We excluded, performed the metaanalysis again, and the results were similar to the initial analysis. However, the number of included studies in the current analyses was small, and additional analyses should be conducted to confirm the present findings.

There were some limitations in the current metaanalysis. Most of studies were of children, but some studies included both children and adults. Independent assessment of the efficacy and safety of CsA in the treatment of SRNS in children and adults is needed. The target renal histological characteristics were MCD, mesangioproliferative glomerulonephritis, MN or FSGS, but not all the studies included these histological characteristics, which increased heterogeneity among the recruited studies.

\section{Conclusions}

In the current meta-analysis, we conclude that CsA is an effective and safe therapy for SRNS. However, additional RCT studies are needed to thoroughly assess the role of CsA in the treatment of SRNS.

\section{Abbreviations}

Cl: Confidence intervals; CR: Complete remission; CSA: Cyclosporine A; MH: Mantel-Haenszel; MMF: Mycophenolate mofetil; NS: Nephrotic syndrome; OR: Odds ratio; P/NT: Placebo/nontreatment; SRNS: Steroid-resistant nephrotic syndrome; TR: Total remission; WMDs: Weighted mean differences

\section{Acknowledgements}

N/A

\section{Authors' contributions}

TBZ conceived and designed the study. HYL, XLZ and TBZ were responsible for the collection of data and performing the statistical analysis and manuscript preparation. HZZ and ZQZ were responsible for checking the data. All authors were responsible for drafting the manuscript, and read and approved the final version.

\section{Funding}

This study was supported by Guangzhou Medical Key Discipline Construction Project (2017-2019).

\section{Availability of data and materials}

All data generated or analysed during this study are included in this published article.

\section{Ethics approval and consent to participate}

N/A.

\section{Consent for publication}

N/A.

\section{Competing interests}

The authors declare that they have no competing interests.

\section{Author details}

${ }^{1}$ Department of Nephrology, Huadu District People's Hospital of Guangzhou, Southern Medical University, Guangzhou, China. ${ }^{2}$ Department of Obestetrics and Gynecology, the Second Affiliated Hospital of Shantou University Medical College, Shantou 515041, China. ${ }^{3}$ Department of Nephrology, the Second Affiliated Hospital of Shantou University Medical College, Shantou 515041, China.

Received: 9 April 2019 Accepted: 9 October 2019

Published online: 23 October 2019

\section{References}

1. Asharam K, Bhimma R, David VA, Coovadia HM, Qulu WP, Naicker T, et al. NPHS2 V260E is a frequent cause of steroid-resistant Nephrotic syndrome in black south African children. Kidney Int Rep. 2018;3(6):1354-62.

2. Varner JD, Chryst-Stangl M, Esezobor Cl, Solarin A, Wu G, Lane B, et al. Genetic testing for steroid-resistant-Nephrotic syndrome in an outbred population. Front Pediatr. 2018;6:307.

3. Dogra S, Kaskel F. Steroid-resistant nephrotic syndrome: a persistent challenge for pediatric nephrology. Pediatr Nephrol. 2017;32(6):965-74.

4. Querfeld U, Weber LT. Mycophenolate mofetil for sustained remission in nephrotic syndrome. Pediatr Nephrol. 2018;33(12):2253-65.

5. Akchurin OM, Kaskel FJ. Late steroid resistance in childhood nephrotic syndrome: do we now know more than 40 years ago? Pediatr Nephrol. 2013;28(8):1157-60.

6. Horinouchi T, Sako M, Nakanishi K, Ishikura K, Ito S, Nakamura H, et al. Study protocol: mycophenolate mofetil as maintenance therapy after rituximab treatment for childhood-onset, complicated, frequently-relapsing nephrotic syndrome or steroid-dependent nephrotic syndrome: a multicenter doubleblind, randomized, placebo-controlled trial (JSKDC07). BMC Nephrol. 2018; 19(1):302.

7. Tullus K, Webb H, Bagga A. Management of steroid-resistant nephrotic syndrome in children and adolescents. Lancet Child Adolesc Health. 2018; 2(12):880-90.

8. Siji A, Karthik KN, Pardeshi VC, Hari PS, Vasudevan A. Targeted gene panel for genetic testing of south Indian children with steroid resistant nephrotic syndrome. BMC Med Genet. 2018;19(1):200.

9. Liu C, Zhu P, Fujino M, Isaka Y, Ito H, Takahashi K, et al. 5-aminolaevulinic acid (ALA), enhances heme oxygenase ( $\mathrm{HO})-1$ expression and attenuates tubulointerstitial fibrosis and renal apoptosis in chronic cyclosporine nephropathy. Biochem Biophys Res Commun. 2019;508(2):583-9.

10. Groenendyk J, Paskevicius T, Urra H, Viricel C, Wang K, Barakat K, et al. Cyclosporine a binding to COX-2 reveals a novel signaling pathway that activates the IRE1alpha unfolded protein response sensor. Sci Rep. 2018;8(1):16678

11. Liu Y, Yang R, Yang C, Dong S, Zhu Y, Zhao M, et al. Cyclophosphamide versus cyclosporine a therapy in steroid-resistant nephrotic syndrome: a retrospective study with a mean 5-year follow-up. J Int Med Res. 2018; 46(11):4506-17.

12. Gellermann J, Ehrich $J H$, Querfeld U. Sequential maintenance therapy with cyclosporin a and mycophenolate mofetil for sustained remission of childhood steroid-resistant nephrotic syndrome. Nephrol Dial Transplant. 2012;27(5):1970-8

13. Loboda A, Mucha O, Podkalicka P, Sobczak M, Miksza-Cybulska A, Kaczara $P$, et al. Kidney injury by cyclosporine a is aggravated in heme oxygenase-1 deficient mice and involves regulation of microRNAs. Acta Biochim Pol. 2018;65(4):613-20.

14. Gellermann J, Schaefer F, Querfeld U. Serum suPAR levels are modulated by immunosuppressive therapy of minimal change nephrotic syndrome. Pediatr Nephrol. 2014;29(12):2411-4.

15. Li ZQ, Hu ML, Zhang C, Wang YM. Efficacy and safety of tacrolimus vs. cyclophosphamide for idiopathic membranous nephropathy: a meta- 
analysis of Chinese adults. J Huazhong Univ Sci Technolog Med Sci. 2015; 35(5):623-8.

16. Choudhry S, Bagga A, Hari P, Sharma S, Kalaivani M, Dinda A. Efficacy and safety of tacrolimus versus cyclosporine in children with steroid-resistant nephrotic syndrome: a randomized controlled trial. Am J Kidney Dis. 2009; 53(5):760-9.

17. Garin EH, Orak JK, Hiott KL, Sutherland SE. Cyclosporine therapy for steroidresistant nephrotic syndrome. A controlled study. Am J Dis Child. 1988; 142(9):985-8.

18. Geng HY, Ji LN, Chen CY, Tu J, Li HR, Bao R, et al. Mycophenolate mofetil versus cyclosporine $\mathrm{a}$ in children with primary refractory nephrotic syndrome. Chin J Pediatr. 2018;56(9):651-6.

19. Lieberman KV, Tejani A. A randomized double-blind placebo-controlled trial of cyclosporine in steroid-resistant idiopathic focal segmental glomerulosclerosis in children. J Am Soc Nephrol. 1996;7(1):56-63.

20. Plank C, Kalb V, Hinkes B, Hildebrandt F, Gefeller O, Rascher W. Cyclosporin A is superior to cyclophosphamide in children with steroid-resistant nephrotic syndrome-a randomized controlled multicentre trial by the Arbeitsgemeinschaft fur Padiatrische Nephrologie. Pediatr Nephrol. 2008; 23(9):1483-93.

21. Ponticelli C, Rizzoni G, Edefonti A, Altieri P, Rivolta E, Rinaldi S, et al. A randomized trial of cyclosporine in steroid-resistant idiopathic nephrotic syndrome. Kidney Int. 1993;43(6):1377-84.

22. Valverde S, Hernandez A, Velasquez L, Romero B, Mendoza A, Ramon G, et al. Efficacy of prednisone-tacrolimus vs. prednisone - Cyclosporine in steroid-resistant nephrotic syndrome. Pediatr Nephrol. 2010;25:1804.

23. Jiang $X$, Shen $W, X u X$, Shen $X, L i$ Y, He Q. Immunosuppressive therapy for steroid-resistant nephrotic syndrome: a Bayesian network meta-analysis of randomized controlled studies. Clin Exp Nephrol. 2018;22(3):562-9.

24. Hodson EM, Wong SC, Willis NS, Craig JC. Interventions for idiopathic steroid-resistant nephrotic syndrome in children. Cochrane database of Syst Rev. 2016;10:Cd003594.

\section{Publisher's Note}

Springer Nature remains neutral with regard to jurisdictional claims in published maps and institutional affiliations.

Ready to submit your research? Choose BMC and benefit from:

- fast, convenient online submission

- thorough peer review by experienced researchers in your field

- rapid publication on acceptance

- support for research data, including large and complex data types

- gold Open Access which fosters wider collaboration and increased citations

- maximum visibility for your research: over $100 \mathrm{M}$ website views per year

At $\mathrm{BMC}$, research is always in progress.

Learn more biomedcentral.com/submissions 